\title{
LEVELS OF RNA FOR TNF- $\alpha$ \\ AND RECEPTORS DURING THE PREREPLICATIVE PERIOD OF LIVER REGENERATION
}

\begin{abstract}
'During the prereplicatioe period of liver regeneration the changes of the $m R N A$ contents for tumor necrosis factor- $\alpha(T N F-\alpha)$ and its receptors were examined in total liver $R N A$ with the help of reverse transcripiase-polymerase chain reaction (RT-PCR) and compared with those after sham operation or stimulation with lipopolysaccharide (LPS). In regenerating liver all the changes are nearly synchronous with a slight delay for the TNF receptor RNAs. The mRNA levels reach their maximum at $1-3 \mathrm{~h}$ after operation and exceed the values for intact animals about ten-fold. The corresponding changes induced by sham operation are quantitatively less than those in the regenerating liver and manifest themselves at the end of the prereplicative period. LPS stimulation induced an increase of TNF-a and TNF receptor production comparable with during regeneration. Analysis of the expression of the $55 \mathrm{kDa} T N F$ receptor revealed qualitative changes, e. $g$. an increased polyadenylation and an imbalance between the amplification of the whole molecule and its $5^{\prime}$-terminal half pointing to as yet unidentified changes at the $3^{\prime}$ end of the motecule.
\end{abstract}

Introduction. Liver regeneration following severe injury is an integral process of secondary organ development in which all types of liver cells participate. Although may features of this reparation resemble processes typical for growth and development of neonatal liver, a number of differences are conspicuous. The most prominent is the loss of the previous adult phenotype with the concomitant adaptative and compensatory reactions; furthermore, responses to stress and local injury differ from the physiological processes of organized proliferation. The main changes triggering the entrance of the injured liver into the cell cycle occur early, during the first $3-4 \mathrm{~h}$ after partial hepatectomy. This phase is considered as the only one preceding the cell cycle and has been named «competence» [1] in accordance with a similar state of mitotically induced fibroblasts [2]. A similar metabolic reorientation follows the first biochemical adaptation reactions called «situation check up» $[3-5]$.

A question less often addressed in research on liver regeneration is the particular role of the non-parenchymal cells. They not only participate in the growth processes by increasing their number, but must also be seen as contributors of signals and mediators of the whole regenerating organ. Among the sinus-lining cells of the liver, the resident macrophages, the Kupffer cells, have been found to be the major producers of stress-related factors that influence the metabolic performance of neighbouring cells [6]. The tumor necrosis factor- $\alpha$ is one of the most potent signal molecules produced by stimulated Kupffer cells that triggers inflammatory and other stress responses in the body $[7,8]$ and in particular after liver injury [9].

Growth factors and cytokines fincluding TNF- $\alpha$ are generally produced by non-parenchymal, a. g. mesenchymal cells. They regulate epithelial cell functions during development and to a great extent also during physiological and different pathophysiological states of the postnatal period. For example, TNF- $\alpha$ is absent or at least significantly decreased during liver regeneration induced in germ-free, athymic or LPS-resistant

- M. YU, OBOLENSKAYA, H, BERNAUER, T.-A. TRAN-THI, K. DECIKER, 1994 
strains of mice or in conventional strains in the presence of antibodies against TNF- $\alpha$. Under these conditions, the release of interleukin-6, the major inducer of acute-phase reactants in the liver, and DNA,synthesis in parenchymal and non-parenchymal cells $[10,11]$ are greatly decreased and sometimes also delayed. On the contrary, prestimulation of rats with LPS that induces TNF-a production in liver macrophages, shortens the premitotic period [12] and increases several manifestations of the regenerating process [13].

Though TNF- $\alpha$ has been suggested to participate in liver regeneration evidence of its production, the responsiveness of the regenerating liver to it and of the mechanisms involved have not yet been provided. The pleiotropic activities of TNF- $\alpha$ include up-regulation of «early» genes and down-regulation of several tissue-specific genes as well as the activation of $2^{\prime}, 5^{\prime}$-oligo $(A)$ synthetase [14], the first link in the chain of specific RNA destruction. These effects make TNF- $\alpha$ a very probable participant in the reorientation of the hepatic metabolism during the transition from the quiescent to the proliferating state.

For this reason the consequences of a two-third hepatectomy for the capacity of liver cells to express the TNF- $\alpha$ gene on one hand and the corresponding receptors on the other was studied on the pretranslational level by estimating the content of specific RNAs during the prereplicative period $(0-12 \mathrm{~h}$ after partia] hepatectomy). Reverse transcription (RT) of RNA coupled with the amplification of individual cDNAs in the polymerase chain reaction (PCR) allowed to detect small quantities of molecules in total RNA without isolation of individual cells or previous enrichment of the samples by RNA fractionation that may produce artifacts $[15,16]$. In addition, it was possible to quantitate the data based on the specific reactivity of each pair of primers, the necessary number of cycles for reliable detection of the product and by comparison of the vield of product with that of a definite quantity of an external standard RNA. To recognize whether the changes at RNA level reflect those of protein production TNF-a toxicity of liver homogenates was tested.

It will be demonstrated that the relative amounts of TNF $\alpha$ and TNF receptor RNAs change nearly synchronously during the prereplicative pe. riod reaching their maximum at $1-3 \mathrm{~h}$ after partial hepatectomy. The increase was specific for the transition from quiescence to proliferation and coincided with the decrease of the relative amount of mRNA for $\mathrm{ri}$ bosomal protein $S 12$. Estimations of TNF- $\alpha$ and TNF receptors RNAs in total liver RNA revealed quantitative and qualitative differences in the RNA production between resting, regenerating and LPS-treated livers supporting the idea of special TNF- $\alpha$ functions during the prereplicative period of liver regeneration.

Materials and methods. $M$ a t e $r$ i a I s. cDNA synthesis kit and $100 \mathrm{bp}$ ladder were purchased from Pharmacia (Freiburg, Germany), Taq polymerase from Stehelin (Basel, Switzerland), T4 polynucleotide kinase from New England Biolabs (Schwalbach, Germany), antibodies to TNF-a from Genzyme (Ismaning, Germany).

We are indebted to Drs C. Galanos and P. Nielsen (Max-Planck-Institut für Immunbiologie, Freiburg, Germany) for purifed LPS from Salmonella minnesota $R 595$ and primers for amplification of S12 cDNA, respectively, and to Dr. G. R. Adolf (Bender, Vienna, Austria) for a recombinant plasmid containing the $55 \mathrm{kDa}$ TNF receptor cDNA and for recombinant murine ( $\mathrm{rm}$ ) TNF-a.

Pretreatment of the animals. For all experiments male Wistar rats $(250-300 \mathrm{~g})$ were used. Partial $(2 / 3)$ hepatectomy and sham operation were performed by standard procedures [17]. Septic shock was induced in intact animals by intraperitoneal injection of $1 \mathrm{ml}$ of a $0.1 \%$ solution of LPS. Livers were excised at $0.25,0.5,1,3,6$ and $12 \mathrm{~h}$ after operations and $1.5 \mathrm{~h}$ after septic shock. Shortly before excision the animals were anesthetized by intraperitoneal injection of $1.0 \mathrm{ml} 20 \% \mathrm{nem}$ - 
butal. Livers were perfused in situ with phosphate-buffered saline (PBS) through the $V$. portare and immediately frozen in liquid nitrogen.

LPS st imulation of whole liver and Kupfer cells. LPS stimulation of the liver was performed by a recirculating liver perfusion in situ with RPMI medium containing $0.5 \mu \mathrm{g}$ LPS $/ \mathrm{ml}$. $1 \%$ newborn-calf serum (NCS), $3.9 \mu \mathrm{M}$ taurocholate, $20 \mathrm{nM}$ glucagon and $50 \mathrm{nM}$ insulin duting $2.5 \mathrm{~h}$. Kupffer cells $\left(6 \cdot 10^{6}\right)$ obtained from intact animals according to Eyhorn et al. [18] were cultured on Falcon dishes for $72 \mathrm{~h}$ and stimulated with $100 \mathrm{ng}$ LPS, $50 \mathrm{U}$ interferon (IFN) $-\gamma / \mathrm{ml}$ in RPMI medium during $1 \mathrm{~h}$. The cells were frozen on the dishes in liquid nitrogen and stored at $-70^{\circ} \mathrm{C}$.

RNA a n a 1 y s i s. Total RNA from frozen tissues or cellular samples was prepared by the guanidinium isothiocyanate method according to Chomchynski and Sacchi [19]. The RNA concentration was determined spectrophotometrically at $260 \mathrm{~nm}$, its purity by the $\mathrm{E}_{260} / \mathrm{E}_{230}$ and $\mathrm{E}_{260} / \mathrm{E}_{280}$ ratios, its integrity by denaturating gel electrophoresis in the presence of formaldehyde [20]. Five $\mu \mathrm{g}$ of RNA from each sample were reverse-transcribed in the presence of oligo (dT) or random primers with a cDNA synthesis kit according to the supplier's protocol; depending on the initial RNA abundance $1 / 30$ to $1 / 10$ of the resulting mix was subjected to PCR. $10 \mu l$ of the final PCR volume contained the respective amount of cDNA, $0.5 \mathrm{U}$ Taq polymerase, 3 pmol each of $5^{\prime}$ - and $3^{\prime}$-primers and $2 \cdot 10^{5} \mathrm{cpm}$ of $\left(\gamma^{-32} \mathrm{P}\right)$ ATP end-labelled $5^{\prime}$-primer. Denaturation was done at $94^{\circ} \mathrm{C}$ for 1 min, annealing at the temperature specific for each pair of primers for $1 \mathrm{~min}$ and extension at $72^{\circ} \mathrm{C}$ during $1-3 \mathrm{~min}$ depending on the length of product. The first denaturation and the last extension step were extended by 5 and $25 \mathrm{~min}$, respectively. To avoid nonspecific primer annealing the PCR was initiated by a hot start. To detect specific PCR products the probes were subjected to a $5 \%$ non-denaturing polyacrylamide gel electrophoresis in parallel with an end-labelled 100 bp ladder. The gels were subsequently soaked for $1 \mathrm{~h}$ in $10 \%$ acetic acid $/ 10 \%$ methanol and dried. Under control by autoradiography the appropriate bands were cut out and their radioactivity was measured by Cherenkov effect. The product was identified by its length and by restriction analysis.

Primers for the polymerase chain reactions. The primers were selected with the help of the «Oligo» program, version 4 [21] and synthesized with an automated nucleotide synthesizer. Some characteristics of the primers and the corresponding products of amplification are presented in Table 1. 5'-Primers were end-labelled with $\left(\gamma^{32 \mathrm{P}}\right)$ ATP $(5000 \mathrm{Ci} / \mathrm{mmol})$ in the T4 polynucleotide kinase reaction $[20]$.

Table 1

Characteristics of PCR primers and $P C R$ products

\begin{tabular}{|c|c|c|c|}
\hline Spectfteity & Sequence & Position & $\underset{\mathrm{bp}}{\text { Length. }}$ \\
\hline TNF $\propto \propto$ & $\begin{array}{l}\text { 5'ATG AGC ACA GAA AGC ATG ATC } 3^{\prime} \\
5^{\prime} \text { CAT ATG TCA CAG AGC AAT GAC TCC } \\
\text { AAA } 3^{\prime}\end{array}$ & $\begin{array}{c}1-21 \\
684-707\end{array}$ & $716^{*}$ \\
\hline $\begin{array}{l}\text { TNF receptor, } \\
55 \mathrm{kDa}\end{array}$ & $\begin{array}{l}5^{\prime} \mathrm{GCC} \text { ACA AAG GAA CCT ACT } 3^{\prime} \\
\text { 5'GAT AAC CAG AGG CAA CAG } 3^{\prime} \\
\text { 5'GCC ACA AAG GAA CCT ACT } 3^{\prime} \\
5^{\prime} \text { TTT TTC TCC ACA ATC ACC TC } 3^{\prime}\end{array}$ & $\begin{array}{c}422-439 \\
874-891 \\
422-439 \\
1881-1901\end{array}$ & $\begin{array}{r}470 \\
I 480\end{array}$ \\
\hline $\begin{array}{l}\text { TNF receptor, } \\
75 \mathrm{kDa}\end{array}$ & $\begin{array}{l}5^{\prime} \mathrm{CAG} \mathrm{CCA} \mathrm{GAG} \mathrm{CCC} \mathrm{ACA} \mathrm{GAT} 3^{\prime} \\
5^{\prime} \text { AGC AGA CCC AGT GAT GTC A } 3^{\prime}\end{array}$ & $\begin{array}{l}698-716 \\
846-864\end{array}$ & 167 \\
\hline$S / 2$ & $\begin{array}{l}5^{\prime} \mathrm{GGA} \text { AGG CAT AGC TGC TGG } 3^{\prime} \\
5^{\prime} \mathrm{GGA} \text { GCT ACT GTA GGA ACC } 3^{\prime}\end{array}$ & $\begin{array}{c}65-82 \\
415-432\end{array}$ & 369 \\
\hline
\end{tabular}

*3'-primer has additional 9 nucleotides at 5 ' end. 
Determination of TNF- $\alpha$. The production of TNF- $\alpha$ in the liver was determined with the L929 cell cytotoxicity assay [22]. Briefly, the pieces of liver were homogenized in sterile RPMI medium, sonicated 5 times during 5 seconds with 30 second intervals and centrifuged at $10000 \mathrm{~g}$. Ail procedures were carried out at $4{ }^{\circ} \mathrm{C}$. Serial dilutions of the supernatant were added to L929 cells. The degree of cytotoxicity was compared with that of $\operatorname{rmTNF}-\alpha$. TNF- $\alpha$ antibody-treated samples were used to control the specificity of the reaction.

Results. Synthe sis of a TNF- $\alpha-d$ erived standard RNA. To monitor the reproducibility of the RT-PCR procedure and establish a

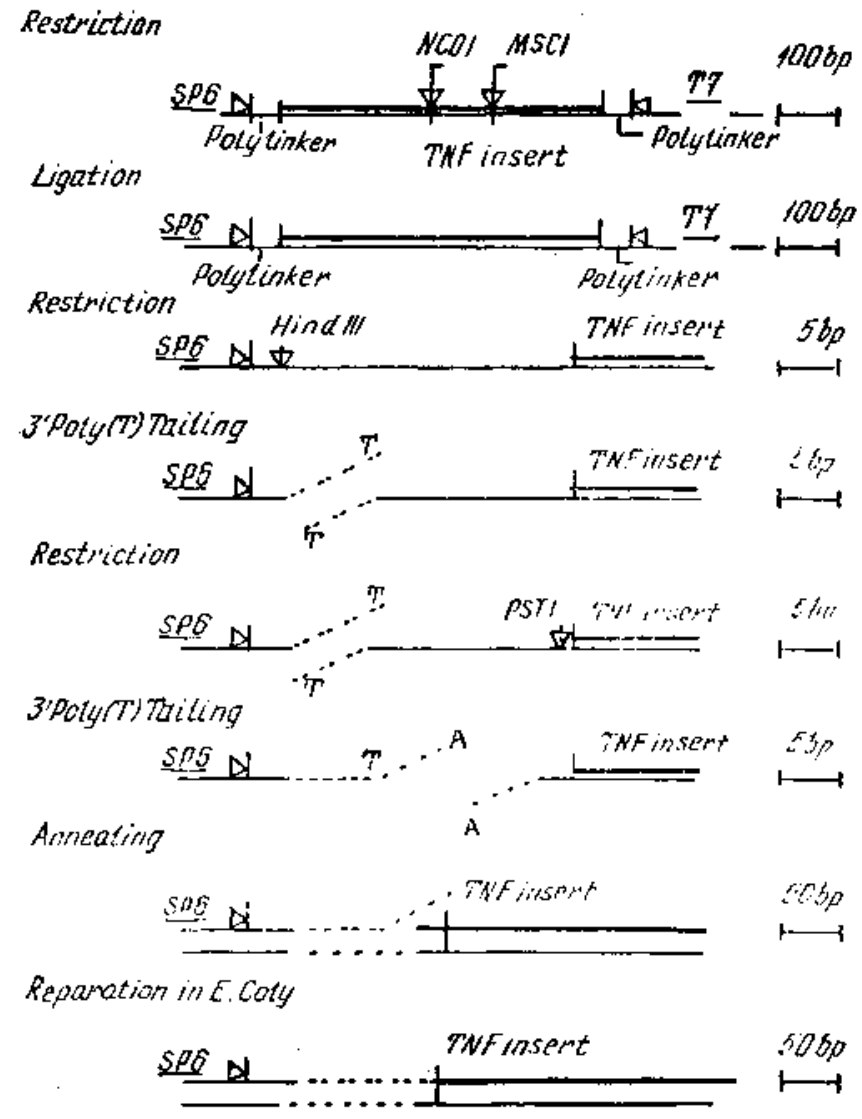

Fig. 1, Modification of the plasmid pSPT18 for the synthesis of a TNF- $\alpha$-related standard RNA

reference for the quantitation of the products, a non-biological RNA whose structure was closely related to that of native TNF- $\alpha$ mRNA was constructed. The plasmid $p S P T 18$ containing the rat-specific TNF- $\alpha$ insert [23] was used as initial sequence for the modifications presented in Fig. 1. Poly (A) -tailed and abrogated TNF- $\alpha$ sense RNA was synthesized by the $\mathrm{T} 7$ polymerase reaction $[24]$ and purified on an (oligo-dT)cellulose column. According to its sequence the molecular weight of the reference RNA was $250 \mathrm{kDa} ; 0.25 \mathrm{pg}$ corresponded to 1 attomol or $6 \cdot 10^{5} \mathrm{mo}$ lecules. Due to their different electrophoretic mobilities, the PCR products derived from the native TNF- $\alpha$ RNA $(716 \mathrm{bp})$ and the standard $(585 \mathrm{bp})$ RNA could be easily separated in $2 \%$ agarose or $5 \%$ non-denaturing polyacrylamide gel electrophoresis.

Kinetics of the reverse transcriptase-polymerase chain reaction with standard TNF-a poly (A)+RNA. Definite amounts of standard TNF- $\alpha$ poly (A)+RNA were subjected to RP-PCR. The kinetic parameters were calculated on the basis of the PCR 
equation $Y=A_{0}(1+R)^{n}$, where $Y==$ quantity of terminal PCR product (here radioactivity of the band), $A_{0}=$ =initial amount of amplifying cDNA, $R=$ coefficient reflecting the annealing efficiency between primers and corresponding DNA sequences and $n=$ number of cycles. From the slope of each curve $R=0.4 \pm 0.05$ was obtained. The validity of this parameter was confirmed by shift values between the graphs for different concentrations. Approximation of all data to constant $A_{0}$ or $n$ yields a single line (Fig. 2).

RNAs for TNF-a and TNF receptors of livers af. ter partial hepatectomy or sham operation. Each serial estimation of individual RNAs in total liver RNA after different

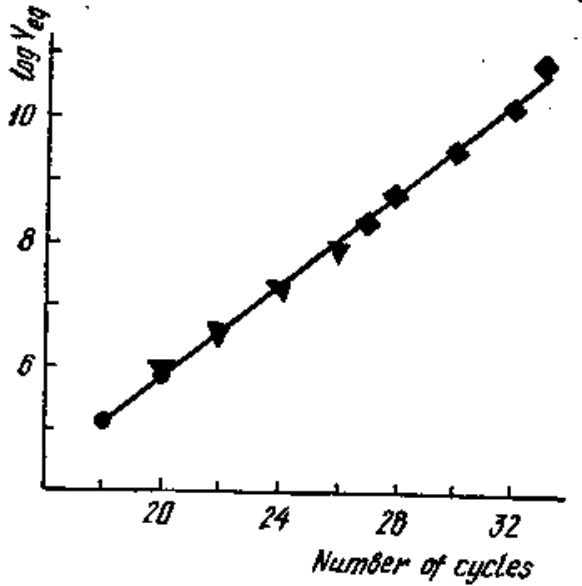
stimulations was preceded by test experiments. They served to define the linear region of amplification for each product and the dependency of the yield of product on the individual RNA redundancies in total RNA

Fig. 2. Equivalent amount of PCR product $\left(Y_{\text {eq }}\right)$ as a function of amplification cycles. The amounts of PCR product $\left(Y_{1}\right)$ from different initial amounts of standard RNA $\left(A_{0}\right)$ were approximated to $Y_{\mathrm{eq}}$ at $A_{\mathrm{c}}=$ $=25 \mathrm{fg} / 10 \mu \mathrm{l} P C R \mathrm{mix}$ and plotted against the number of the cycles. $A_{0}: 660 \mathrm{fg}(\mathrm{O})$. $110 \mathrm{fg}(\Delta), 11 \mathrm{fg}(\boldsymbol{a})$ of standard RNA. For details, see Materials and Methods

and on the initial concentration of total RNA used in RT-PCR. The typical dependence of the amount of specific product on the number of amplification cycles is shown in Figs 3 and 4.

The amounts of PCR products obtained from TNF- $\alpha$ and TNF receptor RNAs reached their maxima at $1-3 \mathrm{~h}$ after partial hepatectomy (with a slight delay for the TNF receptors) and at $6-12 \mathrm{~h}$ after sham.

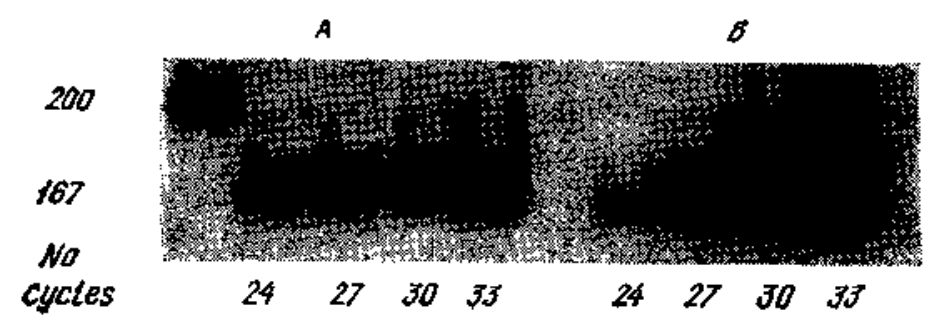

Fig. 3. Arrount of $75 \mathrm{kDa}$ TNF receptor-related RT.PCR product in liver RNA from intact $(A)$ and LPS-stimulated $(B)$ rats. $A_{0}=0.5 \mu \mathrm{g}$ total RNA

operation. The value of the PCR product specific for the $55 \mathrm{kDa}$ TNF receptor passed through a minimum at $0.5 \mathrm{~h}$ after partial hepatectomy before reaching its maximum at $3 \mathrm{~h}$ after partial hepatectomy (Figs $5-7$ ). Amplification of the same cDNA probes with primers specific for the S12 RNA revealed quite different kinetics. The amount of product decreased at $0.25-1 \mathrm{~h}$ in the hepatectomized liver and increased thereafter steadily with time (Fig. 5). After sham operation the changes of $\mathrm{S12}$ ¿RNA were less pronounced but possessed the same tendency.

The amount of products formed depended on the nature of the primers used in RT-PCR. Higher amount of terminal products were synthesized in random-primed than in oligo(dT)-primed cDNA synthesis for each type of amplification. The difference between the two kinds of reactions remained nearly the same for TNF- $\alpha$-specific amplifications in samples from partially hepatectomized, sham-operated or intact animals. 
Two different $3^{\prime}$-primers for amplification of cDNA encoding the $55 \mathrm{kDa}$ TNF receptor were examined. In both reactions the $5^{*}$-primer was the same. It annealed to the sequence 63 bp dowristream from $5^{\prime}$-end of the region encoding the soluble part of receptor or to the junction of the second and third exons. The position of the latter was localized by comparative computer analysis of the human [25] and rat [26] cDNAs. One of the $3^{\prime}$-primers (position 1881-1901 bp) hybridized with the sequence corresponding to the non-translatable $3^{\prime}$-region of the intracellular part of the receptor $229 \mathrm{bp}$ upstream from the $3^{\prime}$-end of the whole cDNA. Used

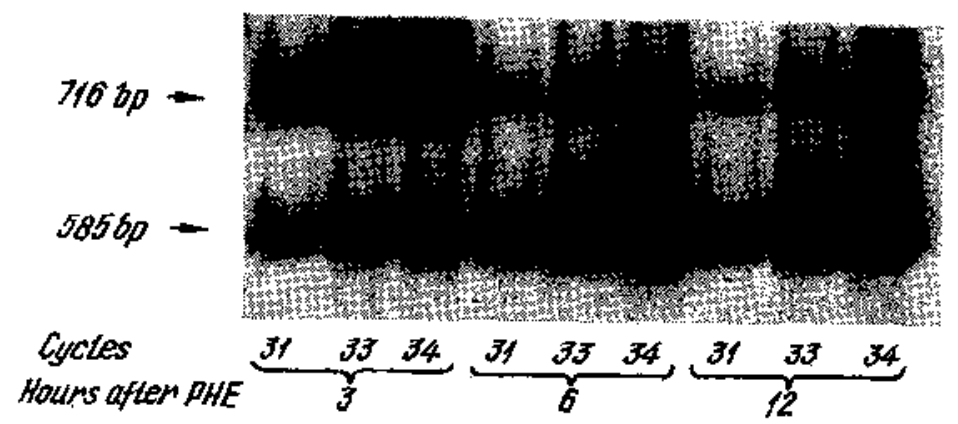

Fig. 4. TNF-a-related RT-PCR products in the samples of total RNA from regenerating liver in the presence of the standard RNA. $A_{0}=0.5 \mu \mathrm{g}$ total RNA $+2.5 \mathrm{fg}$ standard RNA. PHE, partial hepatectorny

together with the $5^{\prime}$-primer in the polymerase chain reaction they gave a 1480 bp product corresponding to the whole receptor with a short abrogation from the $5^{\prime}$-end. Another $3^{\prime}$-primer (position $874-891 \mathrm{bp}$ ) annealed to the sequence corresponding to the transmembrane part (871-

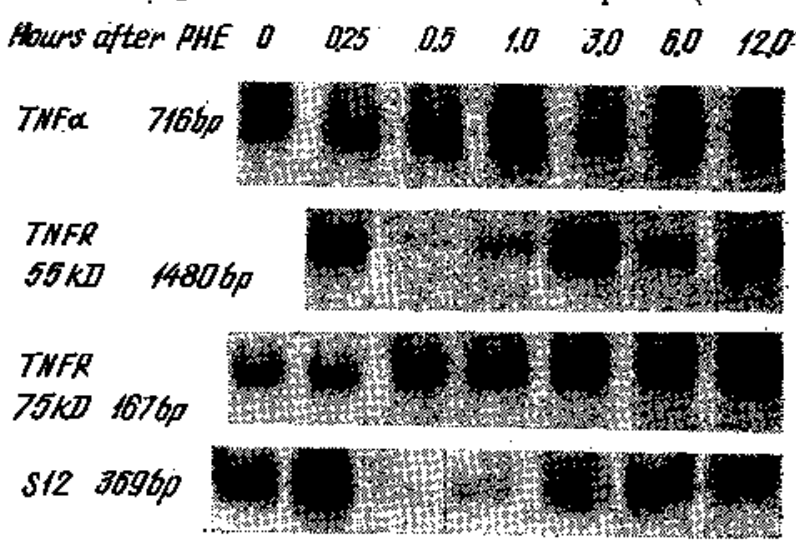

Fig. 5. RT.PCR products related to TNF- $\alpha, \mathrm{TNF}$ receptors and ribosomal protein $S 12$ frem total liver RNA after partial hepatectomy. $A_{0}$ is the same as in the Fig. 3 ; ${ }^{*} n=20 \mathrm{cy}$ cles; ** $A_{0}=0.08 \mu \mathrm{g}$ total RNA. The numbers of cycles were $32,25,30$ and 20 for the amplification of CDNA related to TNF-a, $55 \mathrm{kDa}, 75 \mathrm{kDa}$ TNF receptors and the ribosomal protein $S / 2$ respectively

$967 \mathrm{bp}$ ) of the receptor and together with the $5^{\prime}$-primer gave a $470 \mathrm{bp}$ product, mainly corresponding to the soluble part of the TNF receptor. With the same number of cycles, the amount of the 1480 bp RT-PCR product was definitely less than the amount of the $470 \mathrm{bp}$ species. Nevertheless, the initial concentrations of the corresponding cDNAs should have been comparable taking into account the different amplification rates of both reactions $\left(R_{470} \sim 0.4\right.$ versus $\left.R_{1480} \sim 0.2\right)$. The lesser efficiency of the 1480 bp cDNA amplification can be connected with the presence of an extremely GC-rich stretch that is refractory to PCR amplification [26]. The ratio between both products was nearly constant for the liver samples from intact, sham-operated and partially hepatectomized rats.

TNF- $\alpha$ and TNF receptor RNAs in LPS-t $r$ e a ted $\mathrm{r}$ a $\mathrm{t} 1 \mathrm{i}$ $v$ ers. It has been claimed that TNF- $\alpha$ production after partial hepatectomy may be induced by LPS leading from the gut into the portal blood [27]. To take account of this possibility a comparative series of measure- 
ments was done after LPS stimulation both in the whole animal under conditions leading to septic shock and by liver perfusion in situ. The amounts of PCR products related to TNF- $\alpha$ and both TNF receptors were about one order of magnitude larger in the samples from LPS-treated than in those from intact animals (Fig. 3). The amount of terminal product related to the $55 \mathrm{kDa}$ TNF receptor obtained trom samples of LPS. treated animals revealed a dependence from the various primers used for RT-PCR quite different from that in samples from untreated rats. The

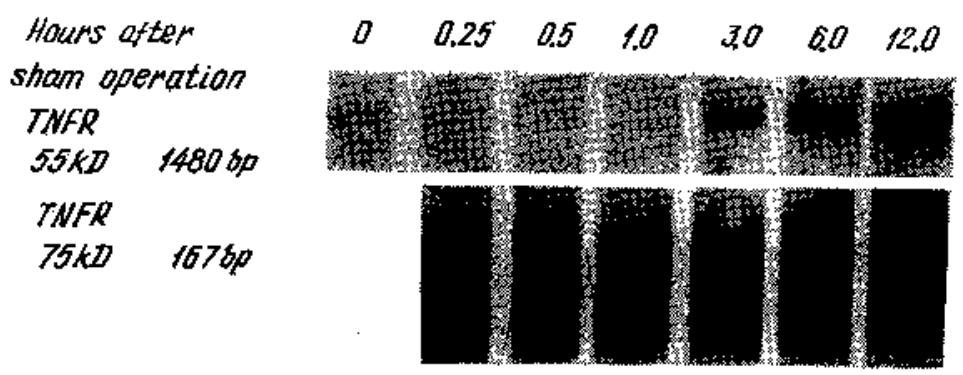

Fig. 6. TNF receptor-related RT-PCR products from total liver RNA after sham operation. $A_{0}$ is the same as in the Fig. 3 . The numbers of cycles were 25 and 30 for the amplifications of the cDNA, to $55 \mathrm{kDa}$ and $75 \mathrm{kDa}$ receptors, respectively

ratio of the $470 \mathrm{bp} 1480 \mathrm{bp}$ products increased two-fold due to the decreased formation of the $1480 \mathrm{bp}$ product. At the same time the difference between the random- and the oligo(dT)-primed amplifications of the 470 bp product was approximately 4 times smaller than in the samples

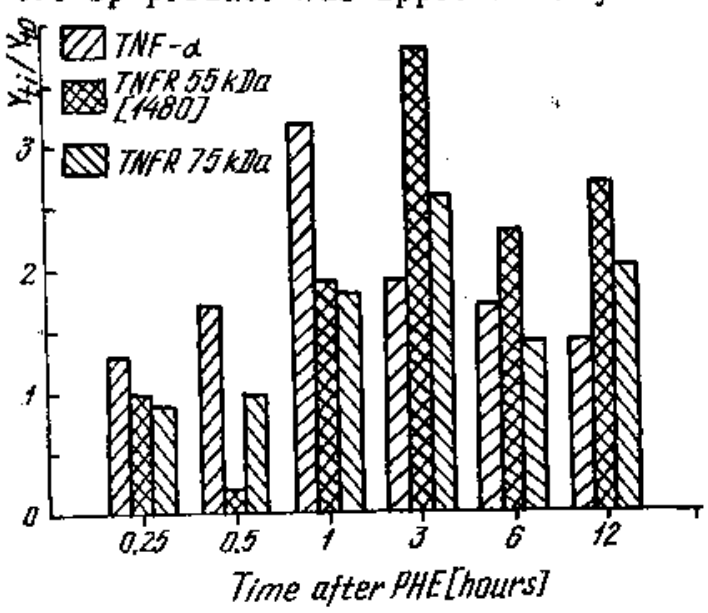
without LPS stimulation because of a more efficient oligo(dT) primed RT-PCR. The level of S12 RNA remained unchanged. It appears that some features of the LPS-stimulated liver differ from those of the regene-

Fig. 7. Changes of the relative amounts of the RT-PCR products related to TNF- $\alpha$ and TNF receptors induced by partial hepatectomy. $Y_{\mathrm{ti}}$ and $Y_{\text {to }}$ are the amounts of RT-PCR products at indicated $\left(t_{i}\right)$ and zero (to) time after operation. PHE, partial hepatectomy; TNFR, TNF
receptor

rating liver. However, the presently available data do not rule out a participation of LPS in the reactions of the liver after partial hepatectomy.

The amounts of TNF- $\alpha$ and TNF receptor RNAs in total liver and in Kupffer cells after different stimuiations. An estimation of the approximate maximal number of TNF- $\alpha$ mRNA molecules per unit of total liver or Kupfier cell RNA after different stimulations is given in Table 2 . The calculation was based on the data obtained by oligo(dT) primed RT-PCR in the presence of TNF-a-derived standard RNA exemplified in Fig. 4. After a definite number of cycles $(n)$ the amount of TNF- $\alpha$-specific full length product ( $Y_{n}$ total RNA $)$, e. $g$. the radioactivity of the appropriate band, was compared with the amount of TNF- $\alpha$-derived shortened product ( $Y_{i \text { standard RNA }}$, obtained in the same reactions. The following assumptions were also taken into consideration: Kupffer cells represent about $15 \%$ by number of all liver cells [28], they contain $2.5 \mu \mathrm{g}$ RNA pro $10^{6}$ cells [29] and they produce the major amount of TNF- $\alpha$ in blood-free liver [6]. 
On the basis of the amplification rates of the individual products, the number of PCR cycles and the amount of terminal products the approximate ratio of TNF-a, TNF receptor (TNFR) RNAs and S12 RNA could be calculated. The abundance of the investigated RNAs in total liver may be arranged in the following order: $S I 2 \sim 55 \mathrm{kDa}$ TNFR> $>75 \mathrm{kDa}$ TNFR $>$ TNF- $a$, where each following member is at least one order of magnitude less abundant than the preceding one. The low level of TNF-a RNA reflects the fact that TNF- $\alpha$ is produced in the liver mainly by Kupfer cells that comprise about $3 \%$ of the tolal liver cell mass.

TNF- $\alpha$ production in the liver. Measurements of the TNF- $\alpha$ content in liver homogenates using the cytotoxicity assay revealed the correspondence between the amounts of specific RNA and protein; maximal cytotoxicity was found in LPS-stimulated livers, less at the maximum of TNF- $\alpha$ RNA expression in regenerating livers and no cytotoxicity in intact livers (data not shown).

Discussion. During the prereplicative period of liver regeneration transient specific manifestations are observed at the pretranslational level of gene expression. The main changes of RNAs encoding TNF- $\alpha$ and TNF receptors occur $\mathrm{l}-3 \mathrm{~h}$ after partial hepatectomy. Quantitatively they are comparable with those obtained with LPS-stimulated animals. The analysis of RT-PCR efficiency with RNA coding for the $55 \mathrm{kDa}$ TNF receptor, however, revealed some qualitative differences between regenerating and LPS-stimulated liver. Assuming that the oligo (dT) and random primers determine reverse transcription of polyadenylated and total RNA, respectively, it is suggested that - in contrast to the regenerating liver - increased polyadenylation contributes to the elevated TNF- $\alpha$ gene expression after LPS stimulation. Additionally, an imbalance exists between the amplifications of the shorter $(470 \mathrm{bp})$ and the longer $(1480 \mathrm{bp}) \mathrm{cDNA}$ species in the livers of endotoxin-treated rats. The decreased amplification of the Iong product coumpled with an increased amplification of the short one (the reverse transcription was oligo(dT) primed for both) reflects some yet unidentified changes in the $3^{\prime}$-end region of the poly (A)+RNA for the $55 \mathrm{kDa} T N F$ receptor that are induced after exposure of the liver to LPS. The changes in the levels of TNF- $\alpha$ and TNF receptor RNAs that were induced by sham operation were much smaller than those in regenerating liver and manifested themselves only at the end of the prereplicative period.

The decrease of the $55 \mathrm{kDa}$ TNF receptor mRNA at the early stage of the regenerating process $(0.25-1 \mathrm{~h}$ after partial hepatectomy) corresponds to the down-regulation of TNF receptors considered by many investigators as the consequence of protein kinase $C$ activation (see [26]). This mechanism is also suggested to operate in the regenerating liver but has not yet been experimentally proved.

The elevated level of RNA coding for TNF- $\alpha$ followed by elevated levels of the RNAs coding for both TNF receptors elicits an increased

T a b le 2

TNF-a RNA content in whole tiver and in Kupffer cells after various stimulations

\begin{tabular}{|c|c|c|c|}
\hline \multirow{2}{*}{ Tissue/cells } & \multirow{2}{*}{$\frac{Y_{n} \text { tot RNA }}{Y_{n} \text { st RNA }}$} & \multicolumn{2}{|c|}{ TNF- $\alpha$ mRNA molecules per } \\
\hline & & $\mu g$ total RNA & $10^{\circ}$ Kupifer cetls \\
\hline $\begin{array}{l}\text { Intact liver } \\
\text { Sham operated liver, } 12 \mathrm{~h} \\
\text { Regenerating liver, i h } \\
\text { LPS-stimulated liver, in vivo } \\
\text { LPS-stimulated liver, perfusion } \\
\text { Kupffer cells, } 72 \mathrm{~h} \text { in culture } \\
\text { Kupffer cells, } 72 \mathrm{~h} \text { in culture, } \\
\text { LPS-stimulated }\end{array}$ & $\begin{array}{l}0.05-0.30 \\
0.08-0.16 \\
0.13-0.60 \\
4.60-5.10 \\
0.90-1.50 \\
0.50-3.00 \\
1.60-2.00\end{array}$ & $\begin{array}{l}(0.6-3.6) \cdot 10^{3} \\
(0.9-2.0) \cdot 10^{4} \\
(1.6-7.2) \cdot 10^{4} \\
(5.6-6.2) \cdot 10^{4} \\
(1.1-1.8) \cdot 10^{4} \\
(0.6-3.6) \cdot 10^{4} \\
(2.0-2.4) \cdot 10^{5}\end{array}$ & $\begin{array}{l}(0.75-4.5) \cdot 10^{5} \\
(1.1-2.5) \cdot 10^{5} \\
(2.0-9.0) \cdot 10^{6} \\
(6.5-7.4) \cdot 10^{6} \\
(1.4-2.2) \cdot 10^{6} \\
(0.2-0.9) \cdot 10^{5} \\
(4.5-6.0) \cdot 10^{6}\end{array}$ \\
\hline
\end{tabular}


production of the corresponding proteins and thereby defines the tissue responsiveness to TNF- $\alpha$. The latter is due to different signal transduction pathways initiated by the $55 \mathrm{kDa}$ and the $75 \mathrm{kDa} T \mathrm{TF}$ receptor, respectively [30]. The elevated expression of the TNF- $\alpha$ gene points to an increased number or activity of the macrophages in the regenerating liver. An increase of the TNF receptors expressed on hepatocytes might explain the indirect activation of gene expression in the parenchymal (and perhaps also some non-parenchymal) liver cells. Thus, a qualitatively changing cell population of the regenerating liver [31] may lead to a variable response pattern of the whole organ. These changes are temporally limited to the stage of the prereplicative period classified as reorientation of cellular metabolism [32]. One of the striking peculiarities of this stage is the partial restriction and partial activation of genome expression. The former manifests itself in a decreased complexity of the nuclear RNA transcribed from protein-coding DNA sequences, delayed transit of newly formed RNA from nucleus to cytoplasm, release of ribosomes from the endoplasmic reticulum [32], and an increased cytoplasmic activity of $2^{\prime}, 5^{\prime}$-oligo (A) synthetase with the tendency to produce oligomers longer than the enzyme from unstimulated livers (unpublished data). It is known that the efficiency to stimulate RNAse $L$ increases with the length of the $2^{\prime}, 5^{\prime}$-oligoadenylate molecules [33]. Since RNAse $\mathrm{L}$ specifically destroys ribosomal and some other yet unidentified mRNAs $[33,34]$, this effect on $2^{\prime}, 5^{\prime}$-oligo(A) synthetase may be responsib]e for the observed decreased expression of the ribosomal protein $\$ 12$. Taken together with observations of an increased production of TNF- $\alpha$ after $\mathrm{CCl}_{4}$ or D-galactosamine treatment [9] the data presented here support the notion of an important role of TNF- $\alpha$ in bringing about the metabolic reorientation after liver injury.

Acknowledgements. The authors thank Dr. Hennig (Geodecke, Freiburg) for the help in primer selection, Dr. G. Igloi (Institut für Biologie II, Freiburg) for synthesis of the primers, Dr. $M$. Kopp for comparative computer analysis of human and rat cDNAs encoding the $55 \mathrm{kDa}$ TNF receptor, $H$. $P$. Henninger for computer design of the figures, Patricia Müller and Alexei Obolenskiy for the help in the preparation of the manuscript.

The research was supported by grants from Deutsche Forschungsgemeinschaft, Bonn, through SFB 154, and from Fonds der Chemischen In. dustrie, Frankfurt- $M$, Germany.

\section{М. Ю. Оболенська, Х. Берноер, Т.-А. Тран-Ті, К. Декер}

РІВНІ РНК, ЯКА КОДУЄ ТNF- $\alpha$ I ПОГО РЕЦЕПТОРИ, ПРОТЯГОМ ПРЕРЕПЛІКАТИВНОГО ПЕРІОДУ РЕГЕНЕРАЦІІ ПЕЧІНҚИ

P е з км е

Нротягом пререплікативного періоду регенерації печінки спостерігалися змјни, вмісту мРНК фактора некроза пухлини (TNF-a) i йог рецепторів у сумарній РНК пеяінки за допомогою зворотної транскрипції та полімеразної ланцюгової реакції. Для порівняння ці ж величини визначали у печінці після несправжньої операції або ліпополісахаридноі стимуляції. $\mathrm{y}$ регенеруючій пецінці всі зміни майже синхронні, 3 невеликим запізненням для РНК рецепторів TNF. Рівні мРНК досягають максимальних значень через $1-3$ год. після операції і приблизно у 10 разів перевищують такі для інтактних твария. Зміни, викликані несправжньою операцією, меньші за величиною, ніж при регенерації, і проявляються у кінці пререплікатнвного періоду. Стимуляція ліпополісахаридами приэводить до росту продукції TNF- $\alpha$ i його рецепторів, порівнянного з таким при регенерації. Аналіз мРНК рецептора TNF масою 55000 засвідчня ямкісні зміня, у тому чнслі збільшення поліадекілювання, $\mathrm{i}$ невідповідність ампліфікації цілоі̄ молекули та і̄і частини, прнлеглої до $5^{\prime}$-кінця, що вказує на поки що не визначені зміни на $3^{\prime}$-кінці молекули. 


\section{REFERENCES}

1. Fousto N., Mead J. E. // Lab. Investigation.-1989.-60.-P. 4-13.

2. Denhardt D. T., Edwards D. R., Parfett C. L. J.// Biochem, et biophys. acta.-1986.865.- P. 83-... 25.

3. Jakoviev A. Yu.//Zitologija.-1979.-21.- P. 1243-1252.

4. Epifanova $O$. I., Terskih V.V., Polunovskij V. A. Quiescent cells. Characteristics and functions in organism.-M. Nauka, 1983.-176 p.

5. Obolenskaya M. Yu., Gerusimova T. B., Bilich K. M., Platorov O. M.//Zitologija i Genetika -1987,-21 - - P. 377-382.

6. Decker K.// Eur. J. Biochem.-1990.-192.-P. 245-261.

7. Decker $K$ K./Molecular aspects of inflammation / Eds. H. Sies., L. Flohe, G. Zim. mer--Berlin, Heidelberg : Springer, 1991.-P. 1-23.

8. Cammussi G., Alabano E., Tetta C., Bussolini F.//Eur. J. Biochem,-1991,-202.P. 3-14.

9. Czaja M. J., Flanders K. C., Biempica $L$. et al. // Growth factors.-1989._1.- P. 219226.

10. Cornell R. P., Liljequist B. L., Bartiral K. F.// Hepatology-- 1990,-11.-_P. 916922.

11. Akermann P., Cote P., Shi Ai Yang et at.//Amer. J. Physiol._1992,-263._P. G579-G585.

12. Mayanski D. N., Scherbakoff V. J.//Biul. Eksp. Biol. i Med.-1979.-86.-P. 69-71,

13. Fisher B., Gebhardt M., Saffer E., Fisher E.//Cancer Res.-1979.-39.-P. 13611367.

14. Krönke M., Schülze S., Scheurich P., Pfizenmaeir K.//Tumor Necrosis Factor/Eds B .B. Aggarwal, J. Viľek.-Dekker, etc., 1992._- P. 189-216.

15. Xanthopoulos K. G., Mikrovitch J., Decker T. et al. // Proc. Nat. Acad. Sci. USA.1989-86.-P. $4117-4121$.

16. Mischoulon D., Rana B., Bucher N. L., Farmer S. R. // Mol. and Cell. Biol--1992.12.- P. 2553-2560.

17. Higgins G. M., Anderson R. M. // Arch. Pathol,-1931,-12,- P, 186-202.

18. Eyhorn S., Schlayer H. J., Henninger H. P. et al.//J. Hepatol.-1988.-P. 23-25.

19. Chomzynski P., Sacchi S. // Anal. Biochem,-1987.-62.-P. 156-159.

20. Sambrook J., Fritsch E., Maniatis T. // Mol. Cloning.-New York: Cold Spring Harbor Lab., 1989.

21. Rychlik W., Rhoads R. E. // Nucl. Acids Res-1989.-17.-P. 8543-8551.

22. Flick D. A., Gifford G. E. J J. Immunol. Meth. -1984.-68.-P. 167-175.

23. Estler H. C., Grewe M., Gausling R. et al. // Biol. Chem. Hoppe-Seyler--1992.$372,-$ P. $271-281$.

24. Gurevich V. V., Pokrovskaya I. D., Obukhova T. A., Zozulya S. A.//Anal. Biochem.1991.-195.- P. 207--213.

25. Fuchs P., Streht S., Dworzak M. et al. // Genomics.-1992.-13.-P. 219-224.

26. Himmler A., Mauer-Fogy l., Krönke M. et al.//DNA and Cell. Biol.-1990-1- p. $705-715$.

27. Mochida S., Ohia Y., Ogata l., Fujiwara K.//J. Hepatol-1992--16-P. 266-272.

28. Blouin A., Bolender $R$. P., Weibet E. R.//J, Cell. Biol -1977,-72.-P, 441-455.

29. Geerts A., Greenwel, $P$., Cunningham $M$, et al. // Cells of the hepatic sinusoid / Eds E. Wisse, D. L. Knook, R. S. McCuskey,-Leiden ; Kupffer Cell foundation, 1991.Vol. 3.-P. 150-154.

30. Tartaglia L. A., Weber R. F. Figari T. S, et al. // Proc. Nat. Acad. Sci. USA.1991.-88.-P. 1292-1296.

31. Mayanski D. N., Scherbakoff V. I., Grishakova A. U.//Experientia.-1980.-36.P. $856 \rightarrow 857$.

32. Obolenskaya M. Yu., Prima V. I., Gerasimova T. B., Platonov O. M.//Biopolymeri i kletka.-1989.-5.-P. $79-88$.

33. Lengyel P. // Ann. Rev. Biochem.-1982.-51.-P. 251-282.

34. Pestka S., Langer I. A., Zoon K., Sammuel C.-E.//Ibid.-1987.-56.-P. 727-777.

Biochemisches Institut, Universität Freiburg, Germany

Institute of Moiecular Biology and Genetics

26.01 .94

Nat. Academy of Sciences of Ukraine, Kiev 